\title{
Stap voor stap naar een gezonder leven voor iedereen
}

Citation for published version (APA):

Nagelhout, G. (2021). Stap voor stap naar een gezonder leven voor iedereen. Maastricht University. https://doi.org/10.26481/spe.20210319gn

Document status and date:

Published: 19/03/2021

DOI:

10.26481/spe.20210319gn

Document Version:

Publisher's PDF, also known as Version of record

\section{Please check the document version of this publication:}

- A submitted manuscript is the version of the article upon submission and before peer-review. There can be important differences between the submitted version and the official published version of record.

People interested in the research are advised to contact the author for the final version of the publication, or visit the DOI to the publisher's website.

- The final author version and the galley proof are versions of the publication after peer review.

- The final published version features the final layout of the paper including the volume, issue and page numbers.

Link to publication

\footnotetext{
General rights rights.

- You may freely distribute the URL identifying the publication in the public portal. please follow below link for the End User Agreement:

www.umlib.nl/taverne-license

Take down policy

If you believe that this document breaches copyright please contact us at:

repository@maastrichtuniversity.nl

providing details and we will investigate your claim.
}

Copyright and moral rights for the publications made accessible in the public portal are retained by the authors and/or other copyright owners and it is a condition of accessing publications that users recognise and abide by the legal requirements associated with these

- Users may download and print one copy of any publication from the public portal for the purpose of private study or research.

- You may not further distribute the material or use it for any profit-making activity or commercial gain

If the publication is distributed under the terms of Article $25 \mathrm{fa}$ of the Dutch Copyright Act, indicated by the "Taverne" license above, 


\section{Stap voor stap naar een gezonder leven voor iedereen}

Inaugurele rede door prof. dr. Gera Nagelhout

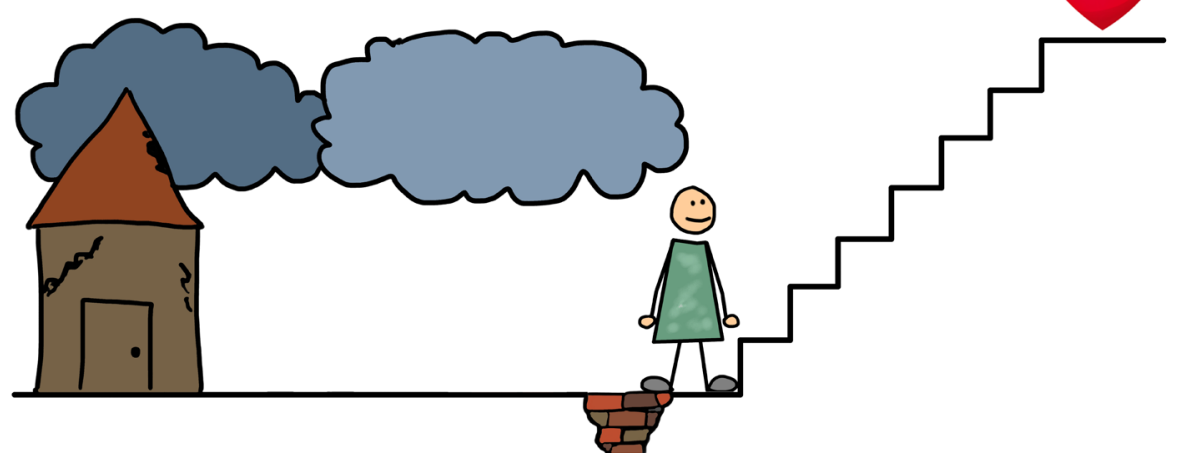





\section{Stap voor stap naar een gezonder leven voor iedereen}

Inaugurele rede door prof. dr. Gera Nagelhout

Maastricht, 19 maart 2021 
Prof. dr. Gera Nagelhout

\section{Colofon}

Ontwerp en opmaak: Gerard van Vliet

Illustraties: Gera Nagelhout 
Geachte rector, beste collega's, vrienden en familie. De komende drie kwartier vertel ik jullie graag iets over mijn leerstoel. Mijn leerstoel gaat over de gezondheid en het welzijn van mensen met een lagere sociaaleconomische positie.

Gezonder gaan leven is niet altijd makkelijk. Je kunt het vergelijken met een hoge trap die moeilijk te beklimmen is; een trap waarvan je soms weer een stukje naar beneden valt, of soms zelfs helemaal. Maar als je stap voor stap door blijft gaan, dan kun je de bovenste trede bereiken. Gewicht verliezen, meer groente en fruit eten, meer bewegen of stoppen met het gebruik van alcohol, tabak of andere drugs, dat kan erg lastig zijn; zélfs als alles in je leven meezit en je uit een ondersteunende, welvarende omgeving komt. Daarom is er langdurige ondersteuning beschikbaar, om mensen te helpen om een gezonde leefstijl te bereiken én deze leefstijl vol te houden.

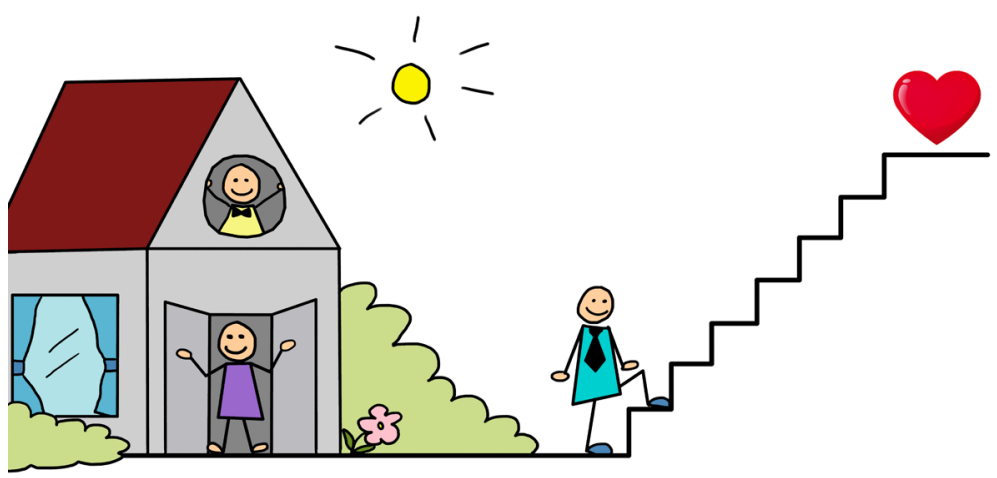

Maar die trap naar een gezonder leven ziet er niet voor iedereen hetzelfde uit. Mensen met een lagere sociaaleconomische positie - met bijvoorbeeld een lager opleidingsniveau of een lager inkomen - hebben vaak een veel lastiger leven. Zeker bij mensen met financiële problematiek loopt de stress vaak hoog op. Er is dan weinig mentale ruimte bij die personen om na te denken over bijvoorbeeld groente en fruit eten of stoppen met roken. Zij hebben zulke grote zorgen over het halen van 
het einde van de maand met het resterende huishoudgeld, dat gezond leven voor hen geen prioriteit heeft. Sterker nog, vet en zoet eten of het gebruik van middelen als tabak of alcohol voelt op zo'n moment als een oplossing om de zorgen even te vergeten. Bovendien komt laaggeletterdheid veel meer voor onder mensen met een lagere sociaaleconomische positie. En mensen die laaggeletterd zijn, hebben vaak moeite met lezen, schrijven, rekenen en werken op een computer. Dit maakt het voor hen lastiger om informatie over gezond leven op te zoeken en te begrijpen.

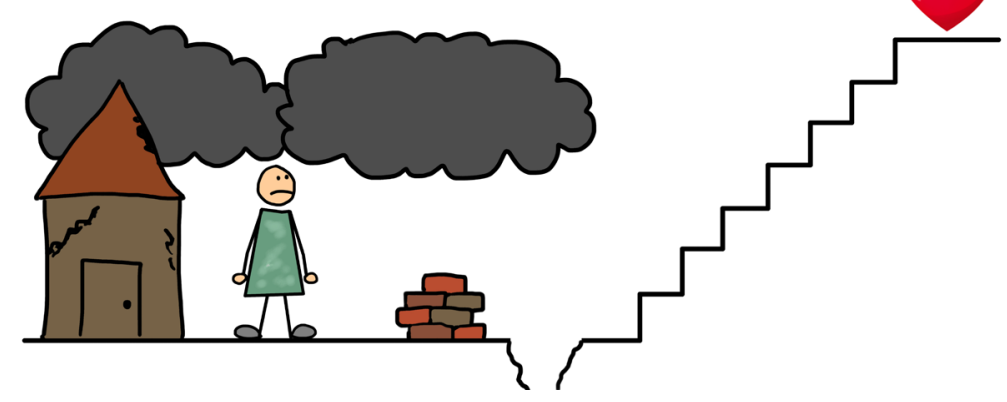

In deze video vertelt Gera Nagelhout over sociaaleconomische gezondheidsverschillen

Blog 'Schulden en toch roken: hoe kan dat?' door Margriet Lenkens

In dit radioprogramma vertelt Gera Nagelhout over sociaaleconomische verschillen in roken

Vaak doet een lagere sociaaleconomische positie en een ongezonde leefstijl zich niet in slechts in één generatie voor. Een lager inkomen of schulden, een lager opleidingsniveau en een ongezonde leefstijl worden vaak doorgegeven van generatie op generatie. Natuurlijk geldt dit niet voor iedereen met een lagere sociaaleconomische positie. Er zijn ook veel mensen die van weinig geld moeten rondkomen en toch gezond leven. Het verschil in gezondheid tussen mensen met een lagere en 
hogere sociaaleconomische positie waarover ik het heb, is gebaseerd op onderzoek naar gemiddelden. Uit dat onderzoek weten we dat mensen met een lager opleidingsniveau gemiddeld zes jaar eerder overlijden dan mensen met een hoger opleidingsniveau. Een nog groter verschil zien we in het gemiddelde aantal jaren dat iemand zich gezond voelt. Mensen met een lager opleidingsniveau voelen zich gemiddeld vijftien jaar minder lang gezond dan mensen met een hoger opleidingsniveau.

Achter al die gemiddelden schuilen natuurlijk echte mensen met ieder een eigen verhaal dat niet altijd in lijn is met het gemiddelde. Bijvoorbeeld het verhaal van mijn eigen familie. De ouders van mijn moeder moesten rondkomen van een minimuminkomen en mijn oma had een verstandelijke beperking. Dit maakte gezond leven lastig, zeker nadat mijn opa heel vroeg overleed aan een hartaanval en mijn oma in haar eentje het gezin draaiende moest houden.

Mijn moeder ging naar de huishoudschool, trouwde en kreeg vier kinderen. Er waren periodes van financiële stress in ons gezin. Toch aten we gezond, want mijn ouders vonden gezond eten belangrijk en mijn vader had een eigen groentezaak. Mijn vader rookte, maar leerde ons dat wij dat beter niet konden gaan doen. Helaas overleed ook onze vader veel te vroeg. Aan kanker, veroorzaakt door het gebruik van alcohol en tabak.

In ons gezin werden wél de intergenerationele patronen doorbroken. Mijn moeder is gaan studeren en behaalde haar diploma. Ook ik en mijn zussen en broer maakten een opleiding af. We hebben geen geldzorgen en we leven gezond. Hoe kan het dat in ons gezin het patroon wel werd doorbroken? Als ik het achteraf probeer te analyseren, dan is dat denk ik een combinatie geweest van onze opleidingen, de open communicatie in ons gezin, de vaardigheden van mijn moeder en het sociale netwerk om ons heen. Zonder deze factoren had ik hier nu waarschijnlijk niet mijn oratie in de gezondheidswetenschappen gehouden. 


\section{Het verhaal van Frank en Irene}

Bij veel andere gezinnen loopt het niet zo en blijven de patronen van weinig geld en ongezond leven van generatie op generatie bestaan. In november 2016 leerde ik zo'n gezin kennen: een echtpaar, laten we hen Frank en Irene noemen, met twee dochters. Ik kwam bij hen thuis voor een interview dat onderdeel was van een onderzoek naar gezinnen met hulpverlening voor multiproblematiek. Als ik aan ze terugdenk, dan zie ik een heel sociaal en gezellig huishouden voor me. Frank en Irene zijn hele lieve mensen die voor iedereen klaarstaan, net als hun dochters. Naast het interview over hun eigen leefstijl hebben ze geholpen met het ontwikkelen van een leefstijlprogramma voor andere mensen met multiproblematiek. Ook hun twee dochters gingen verschillende keren mee naar het buurthuis om met ons mee te denken. Ik heb dus vooral hele goede herinneringen aan dit lieve en behulpzame gezin, maar hun problemen zijn tegelijkertijd onbeschrijfelijk zwaar. Om hun verhaal te kunnen vertellen tijdens deze oratie las ik de transcripten terug van het eerste gesprek dat ik met ze had. En dat is dan toch weer even schrikken... Hoewel dit eigenlijk een vrij typisch verhaal is van een gezin met multiproblematiek.

Frank en Irene zitten diep in de schulden en houden daarom weinig geld over voor boodschappen. Ze kopen alleen koffie, suiker, vlees en snoep voor de kinderen in de supermarkt en verder leven ze van het voedselbankpakket. Frank ontbijt nooit en eet's middags zo weinig mogelijk zodat er meer eten overblijft voor de rest van het gezin. Hij vertelt dat aan mij, maar ik mag het niet aan zijn vrouw vertellen, die op dat moment even boven is. Irene krijgt regelmatig geen hap door haar keel vanwege de stress die haar hele lichaam verkrampt. Soms lukt het haar om meerdere keren per dag kleine beetjes te eten. Ze zit al vol - van de stress. Het enige wat ze beide goed wegkrijgen is koffie, véél koffie, mét suiker.

Franks moeder rookte en dronk heel veel. Hij werd op zesjarige leeftijd uit huis geplaatst en kwam in vijf verschillende internaten terecht. Zijn 
broer raakte verslaafd aan alcohol en pleegde zelfmoord. Zelf rookt Frank sinds zijn veertiende. Hij wil wel stoppen, maar daarvoor heeft hij nu te veel stress. Hij drinkt doordeweeks twee halve liters bier per dag en drie tot vier per dag in het weekend. Hij voelt zich niet verslaafd, maar hij wil wel minderen met alcohol voor Irene. Tot nu toe is dat nog niet gelukt.

Irene heeft hele nare ervaringen met alcohol. Ze is vroeger mishandeld door haar vader als hij onder invloed was van alcohol. Ze is bang dat Frank ook die kant op gaat als hij zo doorgaat met drinken. De moeder van Irene heeft nooit gedronken, maar ze rookte wel. Op 65-jarige leeftijd overleed ze aan een hartstilstand in het huis van Irene en Frank. Irene rookt zelf ook en ze heeft heel vaak geprobeerd om te stoppen, maar dat lukt maar niet door de stress. Zowel Frank als Irene hebben een verhoogd cholesterol en de cardioloog geeft aan dat ze écht moeten stoppen met roken. Maar dat is makkelijker gezegd dan gedaan.

Bewegen doet Frank veel en graag. Hij loopt uren in het bos met de hond en soms doet hij dit samen met de kinderen. Irene beweegt slechts vijf tot vijftien minuten per dag, en dan loopt ze een heel klein rondje met de hond. Ze geeft aan dat haar lichaam op het moment niet meer aankan dan dat. De situatie waarin ze zitten, de geldproblemen en de schaamte vergen zoveel energie van haar lichaam, dat bewegen haar niet meer goed lukt. Ze heeft ook geen energie meer om naar vrienden en familie te gaan.

Hun dochters zijn 14 en 17 jaar oud. Zolang Frank en Irene het kunnen bekostigen, kopen ze shag voor hun dochters. Hun gedachte is dat je beter shag van je ouders kunt krijgen dan dat je het van een vriendje krijgt en er drugs in zit. De kinderen bewegen veel en dus maakt het niet zoveel uit als ze ook veel snoepen, ze komen er immers nog niet van aan. Een vriend van de familie neemt elke week snoep voor ze mee en ook Frank en Irene kopen snoep en snacks voor hun dochters zolang er nog weekgeld in hun portemonnee zit. 
Het verhaal van Frank en Irene laat zien hoe patronen van ongezond leven worden doorgegeven van generatie op generatie. Ook laat het zien wat stress door geldproblemen met een mens doet en hoe moeilijk het dan is om gezond te leven, ook als je dit echt wil. Irene zegt over de stress en wat dat lichamelijk met haar doet:

"lk ben nu op dit moment, heeft dit zoveel van mij gevreten dat ik gewoon een wrak ben. Alles doet nu zeer aan m'n lichaam. Ik heb om het minste of geringste hoofdpijn en volgens mijn maatschappelijk werker ben ik depressief. Dat voel ik zelf niet zo. Maar het zal wel! Ik loop gewoon door en ik doe wel wat ik kan doen. En ja, of ik het nou wel of niet kan, ik zal wel moeten. Ik moet me kop boven water houden. Ik moet het gezin draaiende houden."

\section{Focus op bereik}

Een logische reflex is om nu te denken dat we Frank en Irene kunnen helpen met gezonder te leven door hele goede en intensieve ondersteuning te ontwikkelen. En om te denken dat zo'n ondersteuningsprogramma heel veel informatie moet bevatten, aangezien ze vroeger nooit geleerd hebben hoe ze gezond moeten leven. Maar aan een intensief en informatief programma dat helpt om de trap naar een gezonder leven te beklimmen, hebben ze niks als ze de trap niet kunnen bereiken. We moeten ons dus eerst focussen op het bereiken van de trap.

En hiervoor moeten er vier dingen gebeuren:

- Ten eerste moeten we mentale ruimte creëren door hun problemen aan te pakken. Er is schuldhulpverlening nodig, hulpverlening voor andere problematiek, het verbeteren van hun leefomstandigheden en het wegnemen van bestaansonzekerheid. Dit worden ook wel de onderliggende oorzaken van sociaaleconomische gezondheidsverschillen genoemd. Hiervoor is het nodig dat de overheid meer maatregelen gaat nemen, dat hulpverleners meer mandaat en tijd krijgen 
om mensen te helpen en dat hulpverleners uit het sociale en zorgdomein met elkaar gaan samenwerken.

- Ten tweede moeten we drempels weghalen zodat de trap naar een gezonder leven bereikbaar wordt. Er mogen geen financiële drempels zijn bij de ondersteuning voor een gezondere leefstijl. Ondersteuning moet dichtbij geboden worden zodat vervoer geen drempel is. Aanmeldprocedures en taalgebruik moeten eenvoudig zijn. Het helpt ook als mensen eerst vrijblijvend kunnen kennismaken en als ze hulp krijgen bij het aanmelden en bij het vinden en invullen van formulieren voor de zorgverzekering.

- Ten derde is actieve promotie nodig, zodat gezinnen op de hoogte zijn van het bestaan van interventies die de gezondheid bevorderen. We kunnen er niet vanuit gaan dat mensen zelf wel op zoek gaan naar ondersteuning, zeker niet bij mensen met een lagere sociaaleconomische positie of mensen die veel stress hebben door hun problemen. Artsen, hulpverleners en welzijnswerkers moeten hen actief vertellen wat de mogelijkheden zijn en hen doorverwijzen naar de plek waar ze ondersteuning kunnen krijgen. Een persoonlijke aanpak werkt daarbij het beste, door iemand waarmee al een vertrouwensband is opgebouwd.

- En ten vierde moeten we het aantrekkelijk maken om de richting van de trap op te lopen. Hoe we iets aantrekkelijk maken voor een bepaalde groep, moeten we als onderzoekers of beleidsmakers niet zelf proberen te bedenken. We moeten interventies samen met de doelgroep ontwikkelen, waardoor de interventies goed bij hen aansluiten. Interventies moeten niet alleen effectief, maar ook passend, aantrekkelijk en leuk zijn. Want je hebt niks aan een effectieve interventie die niemand gebruikt of volhoudt. Beloningen voor deelname kunnen helpen. Of het inzetten van ervaringsdeskundigen of sleutelpersonen bij de werving. Daarnaast is het belangrijk dat professionals een begripvolle en niet-veroordelende houding hebben. 
Podcast waarin Gera Nagelhout, Ursula Dewkalie en Feroz Hansildaar vertellen over het bereiken en betrekken van mensen in een kwetsbare positie

Blog 'Leefstijl en sociaal netwerk: taken voor sociaal werkers?’ door Gera Nagelhout, Latifa Abidi en Tamar Jansen

Als we deze vier stappen overslaan en ons alleen focussen op het ontwikkelen van effectieve interventies die de gezondheid bevorderen zonder dat we rekening houden met het bereik, dan lopen we het risico dat de gezondheidsverschillen steeds groter worden. Dergelijke interventies die slechts bedoeld zijn om de trap te beklimmen en niet om de trap te bereiken, zijn namelijk vooral geschikt voor mensen met een hogere sociaaleconomische positie. Zij hebben - gemiddeld genomen - een makkelijker leven met veel minder zorgen. Ze hebben minder moeite om actief te zoeken naar hulp en ze kunnen er ook voor betalen.

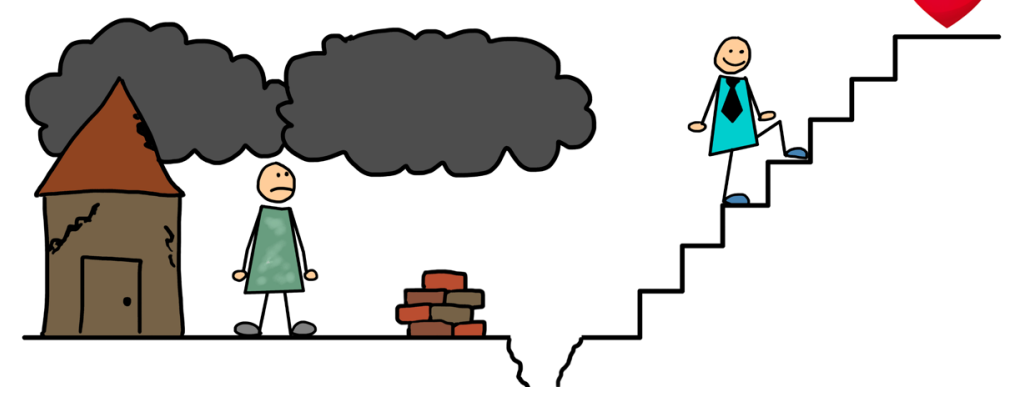

Frank, Irene en hun twee dochters, en ook enkele anderen hielpen mee met de ontwikkeling van een leefstijlprogramma voor mensen met weinig geld en multiproblematiek. We noemden het programma Back2Balance. Deze naam is bedacht en gekozen door de mensen die ons hielpen bij de ontwikkeling van het programma. Het programma was bedoeld voor mensen die al hulpverlening kregen voor multiproblematiek en die door de ergste crisisperiode heen waren. 
Het programma werd erg laagdrempelig: het was gratis en alleen als je mee wilde eten betaalde je een kleine bijdrage. Het was in de buurt; in ontmoetingsplaatsen van de gemeente. En je kon zelf kiezen aan welke activiteiten je mee wilde doen; je zat nergens aan vast.

\section{Video over het Back2Balance-programma}

Podcast waarin Gera Nagelhout en Hermijn Schutte vertellen over het Back2Balance-programma

Blog 'Meer gezelligheid voor multiprobleemgezinnen' door Gera Nagelhout

De kracht van Back2Balance was dat het aantrekkelijk en leuk was voor de mensen voor wie het bedoeld was. Gezelligheid stond centraal en dat het ook nog over gezondheid ging was mooi meegenomen. Hierdoor deden er mensen mee aan het programma die anders nooit over gezonder leven nagedacht hadden. Of die, net als Frank en Irene, dachten dat hen dit toch nooit zou lukken omdat de stress veel te hoog was. De deelnemers waardeerden vooral het feit dat ze andere mensen leerden kennen die ongeveer in hetzelfde schuitje zaten als zij en dat ze samen leuke dingen deden.

Als ik over Back2Balance of over vergelijkbare programma's vertel, krijg ik vaak de vraag of het programma effectief was in het veranderen van leefstijlgedrag. Is het BMI van deelnemers significant gedaald? Zijn ze op de lange termijn meer gaan sporten en gezonder gaan eten? Het antwoord is: nee, dat gebeurde niet. Wat we met Back2Balance gedaan hebben, is mensen even de mogelijkheid geven om weg te stappen van de donkere wolken van hun problemen en een voorproefje te geven van de trap naar een gezonder leven. Het succes van Back2Balance zit ' $m$ erin dat Irene, die nauwelijks haar huis meer uitkwam, toch meerdere keren naar het buurthuis kwam om te helpen bij de ontwikkeling van het programma. Dat Frank extra eten opschepte en genoot van de gezelligheid aan tafel. En dat hun dochters eens een ander uitje hadden dan wandelen met de hond. 


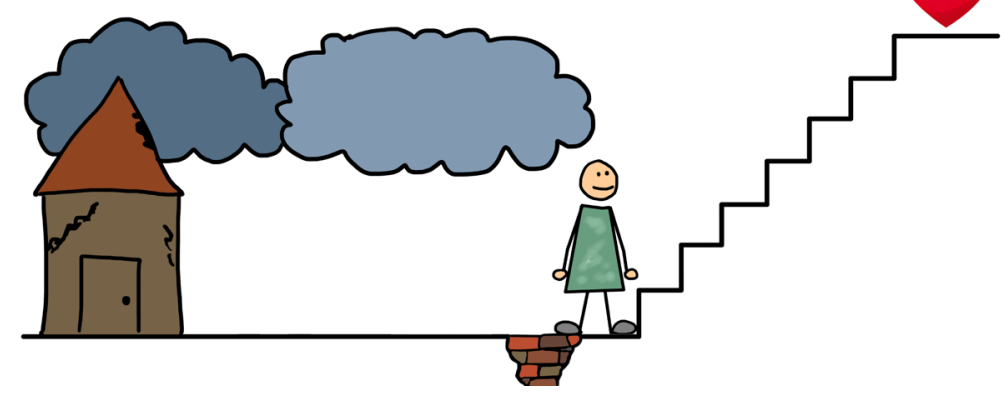

Blog 'Laat de teugels van doelmatigheid wat vieren' door Gera Nagelhout Blog 'Met kleine stapjes naar een gezonder leven' door Gera Nagelhout

Als we mensen willen helpen daadwerkelijk die trap te beklimmen naar een gezonder leven, moeten we ze intensievere ondersteuning bieden die een minder vrijblijvend karakter heeft. Maar dat neemt niet weg dat de mensen eerst bereikt moeten worden. Dat ze verleid moeten worden om mee te doen en dat ze de weg richting de trap moeten afleggen. Eén van de deelnemers van Back2Balance gaf na deelname bij haar huisarts aan dat ze nu echt gemotiveerd was om af te vallen en dat ze daar hulp bij nodig had. Ze mocht meedoen aan de gecombineerde leefstijlinterventie. Dit is een intensief traject van twee jaar waarin je in een groep gezonder leert eten, bewegen en je gedrag leert veranderen. Zonder Back2Balance had ze die stap nooit gezet.

\section{Effect bereik je samen}

Laten we het nu hebben over het bereiken van effect. Hoe ondersteunen we mensen bij het beklimmen van de trap? Het slechte nieuws is dat we dit nog niet volledig weten. Er zijn veel verschillende dingen waar je op moet letten bij goede ondersteuning aan mensen met een lagere sociaaleconomische positie. Al die verschillende dingen wil je eigenlijk tegelijk 
inzetten om iemand zo goed mogelijk te helpen, maar dit maakt het ook lastig om de afzonderlijke elementen wetenschappelijk te onderzoeken.

Het goede nieuws is dat we bijvoorbeeld vanuit kwalitatief onderzoek onder professionals wel een goed beeld hebben van welke elementen waarschijnlijk belangrijk zijn in de ondersteuning aan mensen met een lagere sociaaleconomische positie.

Dit zijn in ieder geval de volgende elementen:

- Groepsondersteuning heeft de voorkeur en kan gecombineerd worden met individuele ondersteuning. Voor veel mensen is ondersteuning in een groep prettig, maar het is vooral belangrijk voor mensen die sociale steun missen in hun eigen netwerk.

- Professionals hebben de juiste houding, kennis en vaardigheden nodig. Belangrijk zijn een niet-oordelende en respectvolle, menselijke houding en een persoonsgerichte aanpak. Qua kennis en vaardigheden kunnen professionals bijvoorbeeld baat hebben bij een opleiding in motiverende gespreksvoering en het herkennen en omgaan met laaggeletterdheid.

- Interventies moeten goed aansluiten bij de doelgroep, bijvoorbeeld door hen bij de ontwikkeling te betrekken. Een flexibele en lerende houding is nodig bij professionals en ontwikkelaars van interventies om deze steeds beter en passender te maken.

- Materialen moeten eenvoudig zijn. Ze moeten niet te talig zijn en bijvoorbeeld ook geschikt zijn voor mensen met laaggeletterdheid.

- De ondersteuning moet gericht zijn op kleine en haalbare veranderingen en moet praktisch ingestoken zijn. Hiermee versterk je iemands vaardigheden en het geloof in eigen kunnen. 
- Het helpt als deelnemers tijdens de ondersteuning leren hoe ze kunnen omgaan met stressvolle situaties. Je ziet namelijk vaak dat mensen gedragsverandering de eerste periode volhouden, totdat er iets stressvols gebeurt en ze terugvallen. Het helpt als je hierop bent voorbereid.

- Interventies voor deze doelgroep moeten intensiever en langer zijn dan reguliere ondersteuning en de interventies bieden idealiter een lange periode van nazorg.

- Interventies kunnen verbeterd worden door een positieve insteek te gebruiken; door het inzetten van beloningen en door de inzet van ervaringsdeskundigen.

- Ten slotte is het niet alleen bij het bereiken van de trap maar ook bij het beklimmen van de trap belangrijk dat de ondersteuning laagdrempelig is en dat er aandacht is voor aanvullende hulp bij onderliggende problemen zoals schulden.

In deze video vertelt Gera Nagelhout hoe ondersteuning voor mensen met een lagere sociaaleconomische positie eruit moet zien

Blog 'De winst van persoonlijke aandacht' door Barbara van Straaten

Ik wil er graag drie elementen uithalen om nog wat nader te bespreken: groepsondersteuning, het inzetten van beloningen en de inzet van ervaringsdeskundigen.

Groepsondersteuning en het inzetten van beloningen deden we in het promotieonderzoek van Floor van den Brand. We deden onderzoek naar groepstrainingen voor stoppen met roken op de werkplek, gecombineerd met een financiële beloning van 350 euro voor wie het lukte om te stoppen met roken. Onze verwachting was dat deze interventie vooral goed zou werken bij mensen met een lager inkomen. 
Onze grootschalige gerandomiseerde studie liet zien dat de financiële beloningen effectief waren in het flink verhogen van het stopsucces van de groepsondersteuning. Maar als we mensen zelf vroegen hoe ze het ervaren hadden, noemden ze vooral de groepsondersteuning als bepalende factor. Sociale steun krijgen van collega's die hetzelfde doormaakten werd erg prettig en helpend gevonden. En er was ook groepsdruk om niet als eerste weer gezien te worden bij het rookhok. Hoewel we in de cijfers zagen dat de beloningen even effectief waren voor mensen met een lager en hoger inkomen, vertelden mensen met een lager inkomen ons vaker dat de beloningen hen extra motiveerden om het stoppen met roken vol te houden. Mogelijk was de hoogte van de beloning vooral voor hen een merkbare stimulans.

Of het financieel belonen van mensen die het lukt om gezonder te gaan leven nu beter werkt bij mensen met een lager inkomen of even goed, het belangrijkste is dat het werkt bij deze groep. En we kunnen dit niet alleen bij stoppen met roken toepassen, maar ook bij het stimuleren van ander gezond gedrag. De grootste uitdaging daarbij is de implementatie. Werkgevers ervaren het belonen van slechts een deel van de werknemers vaak als oneerlijk. Daarom voeren we momenteel implementatieonderzoek uit waarin we onderzoeken hoe we werkgevers kunnen stimuleren om te gaan belonen en hoe we vooral werknemers met een lagere sociaaleconomische positie bereiken.

Animatievideo over het belonen van stoppen met roken

Blog 'Werkgevers moeten massaal stoppen-met-rokenbeloningen inzetten' door Floor van den Brand

Ervaringsdeskundigen worden nog weinig ingezet in de gezondheidsbevordering. Wel wordt de inzet van ervaringsdeskundigheid steeds populairder in de geestelijke gezondheidszorg, waaronder ook de verslavingszorg en forensische zorg. Het inzetten van ervaringsdeskundigen wordt als veelbelovend gezien, maar er is nog weinig bekend over of en hoe het werkt. 
Het promotieonderzoek van Margriet Lenkens richt zich op het inzetten van ervaringsdeskundigheid bij jongeren met delinquent gedrag. Met als doel om hen te helpen weer op het rechte pad te komen. We doen onderzoek naar de mechanismen die in werking treden bij de inzet van ervaringsdeskundigheid. We zien bijvoorbeeld dat ervaringsdeskundigen hoop kunnen bieden dat verandering daadwerkelijk mogelijk is. En dat ze een geloofwaardig rolmodel zijn. Dat ze goed in staat lijken te zijn om empathie te tonen en de cliënt te accepteren zoals hij is, omdat ze zelf ook in die situatie hebben gezeten. En dat ze een realistisch beeld hebben van hoe het herstelproces eruit ziet, omdat ze het zelf hebben meegemaakt. Ook óns onderzoek laat dus zien dat de inzet van ervaringsdeskundigheid veelbelovend is.

\section{Blog '5 mythes over ervaringsdeskundigheid' door Barbara van Straaten}

In deze podcast vertellen Margriet Lenkens, Leonard van der Kolk en een cliënt over ervaringsdeskundigheid in de forensische setting

Blog 'Wees een mens, ook (of juist?) in het forensische werkveld' door Margriet Lenkens

\section{Op weg naar je eigen doel}

Maar hoe zit het nu eigenlijk met die trap? Waar lopen we naartoe en waarom? We zijn stap voor stap op weg naar ons eigen doel.

Frank en Irene hebben hun ervaringskennis gedeeld om te helpen bij de ontwikkeling van het Back2Balance-programma. Waarom deden ze dat eigenlijk? Irene had toch maar zo weinig energie dat ze slechts een paar minuutjes kon wandelen? En op bezoek gaan bij vrienden en familie was toch al te veel gevraagd? En liep de stress bij beiden niet zo hoog op dat ze er niks meer bij konden hebben? Natuurlijk zal meegespeeld hebben dat we ze betaald hebben voor hun tijd. Maar de belangrijkste drijfveer die ik bij hen zag was het willen helpen van andere mensen. "Mensen die 
het écht heel slecht hebben", zoals ze dat zelf noemden. Ook wilden ze mij helpen door het delen van hun ervaringskennis en waren ze trots dat ze zo serieus genomen werden en dat hun inbreng gewaardeerd werd. Het primaire doel van mensen om mee te doen hoeft dus niet altijd een gezonder leven te zijn, het kan bijvoorbeeld ook het verdienen van een beloning zijn of het helpen van andere mensen.

Blog 'Corona en geld als motivatie' door Gera Nagelhout

En gezondheid is ook meer dan goed voor je lichaam zorgen en vrij zijn van ziekte. Het concept 'positieve gezondheid' laat zien dat gezondheid ook gaat over mentaal welbevinden, zingeving, kwaliteit van leven, meedoen en dagelijks kunnen functioneren. Met Frank en Irene ging het bijvoorbeeld steeds beter toen ze anderen gingen helpen. Dit had geen direct effect op hun lichamelijke gezondheid, maar ze gingen wel meer meedoen en hun mentaal welbevinden werd beter.

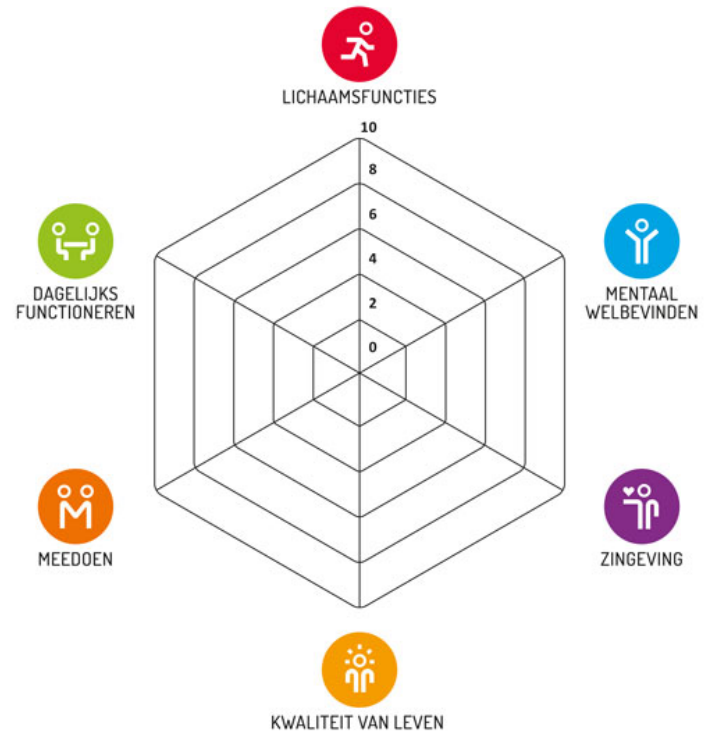

De dimensies van positieve gezondheid (Huber et al., 2014) 
In andere vakgebieden heb je soortgelijke modellen als positieve gezondheid. Bijvoorbeeld positieve criminologie en de herstelbenadering. Wat deze modellen met elkaar gemeen hebben is dat ze niet alleen gaan over de aandoening of beperking, maar om de mens die veel meer is dan dat. Deze modellen gaan ook over het participeren in de maatschappij en het leven van een goed en fijn leven.

In het promotieonderzoek van Thomas Martinelli kijken we op die manier naar het proces van herstel bij drugsverslaving. In dit onderzoek mogen mensen zelf aangeven of ze vinden dat ze in herstel zijn, bijvoorbeeld omdat ze geen drugs meer gebruiken of omdat dit niet meer problematisch voor ze is. We zien dan ook dat niet alle mensen die in herstel zijn helemaal geen drugs meer gebruiken. En dat hoeft ook niet. ledereen kan de keuze maken om de trap naar een gezonder leven maar voor een deel te beklimmen. We zien ook dat mensen die langere tijd in herstel zijn op allerlei vlakken steeds beter functioneren en steeds meer mee gaan doen in de maatschappij. Dit is een lange termijn proces dat zelfs na vijf jaar in herstel nog doorzet.

Video over het Recovery Pathways project

Blog 'Kers op de taart van herstel' door Thomas Martinelli en K.

\section{Terugval hoort erbij}

Maar niet iedereen lukt het om in één keer in herstel te blijven. We moeten accepteren dat terugval erbij hoort. En we moeten de zorg en ondersteuning zo inrichten dat mensen na een terugval ondersteuning kunnen blijven ontvangen zodat ze de draad weer oppakken.

Frank was al 2,5 jaar gestopt met roken toen zijn schoonmoeder en stiefvader kort na elkaar overleden. Toen greep hij toch weer naar de sigaretten. Opnieuw stoppen wil hij wel, maar de therapie die hem de vorige 


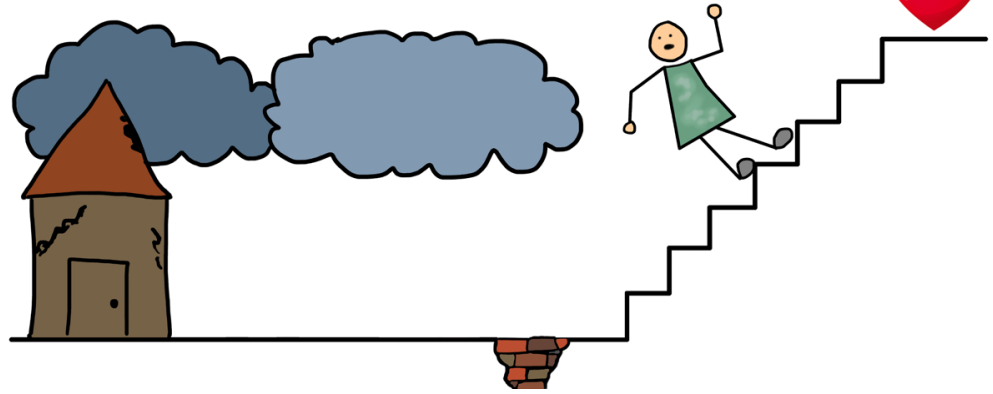

keer geholpen heeft is te duur. Gelukkig wordt inmiddels ondersteuning bij het stoppen met roken vergoed uit de basisverzekering en ook zonder eigen risico. Maar dit is wel voor maximaal één stoppoging per jaar. Bovendien mag je bij groepsondersteuning vaak niet meer mee doen met de groep als je terugvalt, omdat dat beter is voor de anderen in de groep.

Aangezien we weten dat terugval vaak voorkomt en dat dit vooral voorkomt bij mensen met een lagere sociaaleconomische positie, is er een plan nodig voor hoe we deze mensen goed kunnen ondersteunen als ze terugvallen. Een mooi voorbeeld vind ik de gecombineerde individuele en groepsondersteuning van de stoppoli in het Rode Kruis Ziekenhuis in Beverwijk. Hier krijgen mensen individuele ondersteuning als ze terugvallen. En ze mogen weer naar de groep zodra ze twee weken rookvrij zijn. In totaal duurt deze begeleiding een jaar, waardoor je alle moeilijke momenten van het jaar met veel risico op terugval (zoals de zomervakantie en oud \& nieuw) een keertje meemaakt mét ondersteuning.

Het risico op terugval in een ongezonde leefstijl is vele malen groter als er ongezond geleefd wordt in je sociale omgeving, bijvoorbeeld door familieleden. In het promotieonderzoek van Dorine van Namen onderzoeken we naasten van mensen met een alcohol-, drugs-, medicatie- of gokverslaving. Leven in de nabijheid van iemand met een verslaving leidt tot meer risico om zelf een verslaving te ontwikkelen, maar het leidt 
ook tot andere lichamelijke en psychische gezondheidsrisico's. Tevens zien we in het onderzoek van Dorine dat ook in families met een hogere sociaaleconomische positie de verslaving van het familielid vaak leidt tot geldproblemen. In de zorg en ondersteuning voor mensen met een verslaving moet dus ook oog zijn voor hun sociale omgeving. Naasten moeten niet alleen worden ingezet ten behoeve van de behandeling van degene met de verslaving; ze moeten zelf ook actief ondersteuning aangeboden krijgen.

Interview met Dorine van Namen en AnneLoes van Staa over ondersteuning voor naasten van mensen met een verslaving

\section{We zoomen nog even uit}

Tot nu toe had ik het vooral over het individuele niveau, met ook aandacht voor het belang van de sociale omgeving rondom het individu. Maar als we nog iets verder uitzoomen komen we nog meer belangrijke factoren tegen om rekening mee te houden. Het model van Dahlgren en Whitehead laat zien dat alleen hulp bieden op het individuele niveau niet genoeg is. Daaromheen zit de sociale omgeving en de gemeenschap. Als we helemaal uitzoomen dan komen we op het niveau van leef- en werkcondities en omgevingsfactoren.

Ter illustratie vertel ik graag nog iets over een onderzoek dat we vorig jaar uitvoerden naar dakloosheid. De onderzoeksvraag was: hoe kunnen we dakloosheid zoveel mogelijk voorkomen? We vroegen dit aan de mensen die het overkomen was en aan hun hulpverleners. Dakloze mensen leven vaak al lange tijd in armoede voordat ze dakloos worden en een groot deel is zeer laag opgeleid. Dakloze mensen zelf gaven in ons onderzoek aan dat ze niet snel om hulp vragen, een eigenschap die een belangrijke rol speelt bij het oplopen van problematiek. Ze zeggen dat hun dakloosheid waarschijnlijk voorkomen had kunnen worden als ze 


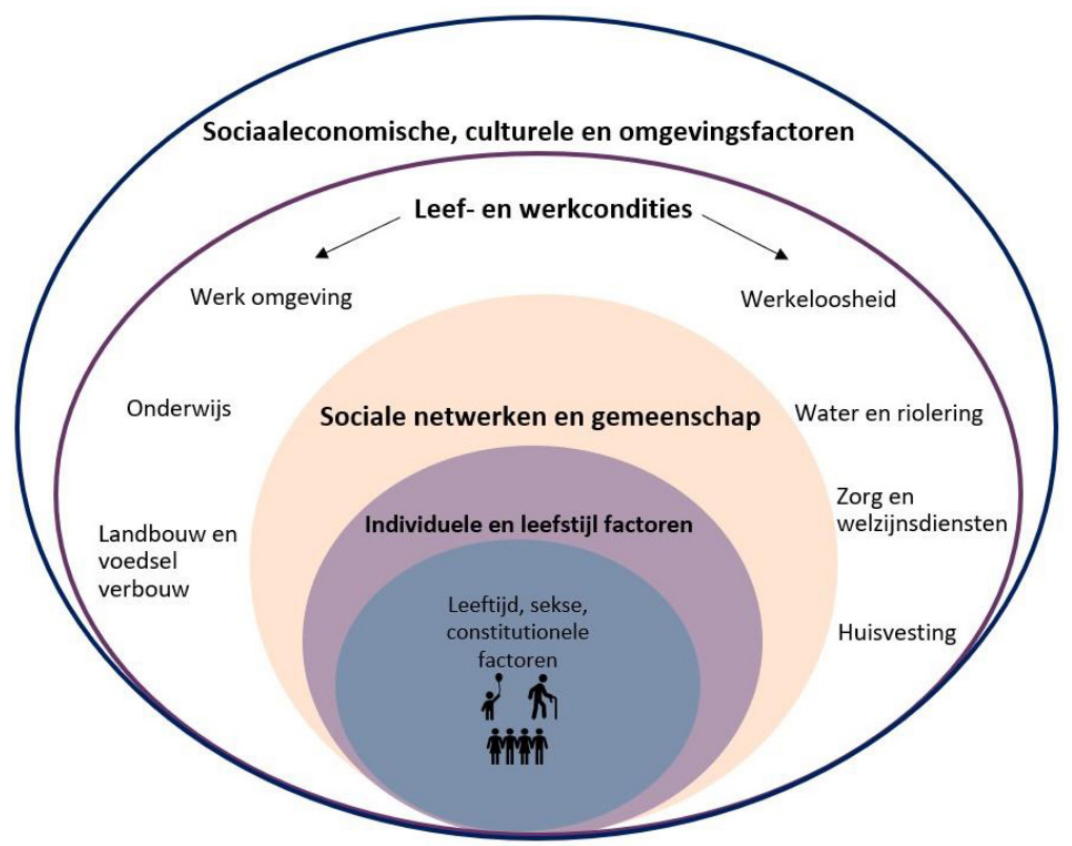

Model Dahlgren \& Whitehead (1991).

zelf anders gehandeld hadden, bijvoorbeeld als ze niet overmatig alcohol hadden gebruikt. Ook geven ze aan dat er meer betaalbare woningen moeten zijn en dat ze meer proactieve of persoonlijke ondersteuning nodig hadden gehad. Hulpverleners geven daarnaast aan dat het ontbreken van een steunend sociaal netwerk een belangrijke risicofactor is voor dakloosheid bij hun cliënten. Dakloosheid los je niet op door op maar één van deze niveaus een interventie in te zetten. Het beschikbaar stellen van een woning is bijvoorbeeld een mooi begin om iemand die dakloos is te helpen, maar daarnaast moet iemand goede ondersteuning krijgen om ook op de andere niveaus stappen te maken.

Blog 'Dakloosheid overkomt niet iedereen' door Barbara van Straaten 
Frank en Irene zijn afhankelijk van de voedselbank. Al jaren is bekend dat voedselbankpakketten veel ongezonde producten bevatten. Zowel Frank als Irene hebben een verhoogd cholesterol en toch eten ze wit brood met hagelslag en koeken, en drinken ze frisdrank uit het voedselbankpakket. De makkelijkste manier om hun voedingspatroon te verbeteren is niet om hen voor te lichten over gezonde voeding (hoewel we dat natuurlijk ook kunnen doen), maar om hun voedselbankpakket simpelweg gezonder te maken. Terwijl bij veel andere interventies het bereik een probleem kan zijn en goedbedoelde initiatieven niet terechtkomen bij de mensen die deze het meeste nodig hebben, is dit een omgevingsinterventie die precies bij de juiste mensen terechtkomt. Alleen mensen met een zeer laag inkomen komen in aanmerking voor de voedselbank en dit is ook de groep die gemiddeld het minst gezond leeft. Hopelijk kan hier snel iets aan gebeuren; vanuit de voedselbank zelf of gestimuleerd door de overheid.

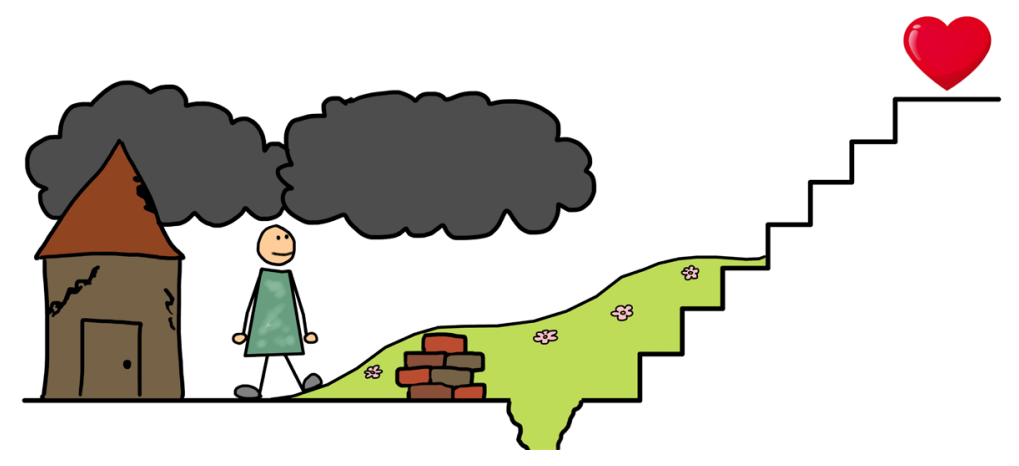

Overheidsbeleid op het gebied van gezondheid kan een enorme impact hebben. En het kan een instrument zijn waarmee we duizenden mensen tegelijk kunnen stimuleren en ondersteunen om gezonder te leven. Met overheidsbeleid kunnen we bijvoorbeeld de fysieke omgeving aanpassen, waardoor gezond leven veel gemakkelijker wordt. We kunnen parken en fietspaden aanleggen, waardoor buiten bewegen aantrekkelijker wordt. Ook kan de overheid met aanpassingen in btw en accijnzen gezonde producten goedkoper maken en ongezonde producten duurder 
maken. Het aantal verkooppunten van alcohol en tabak kan verkleind worden en reclame voor ongezonde producten kan verboden worden. En de overheid kan daarnaast inkomensmaatregelen nemen, werkloosheid aanpakken en de leefbaarheid in buurten verbeteren. Er zijn echter twee problemen: de overheid doet op dit gebied veel te weinig en de industrie werkt tegen.

Blog 'Jongeren en overmatig alcoholgebruik: stop dweilen met de kraan open' door Gera Nagelhout

Blog 'Wie heeft dat hek daar neergezet' door Gera Nagelhout

Twee jaar geleden sloot de overheid met meer dan zeventig maatschappelijke organisaties het Nationaal Preventieakkoord. Daarin staan afspraken om Nederland gezonder te maken op het gebied van overgewicht, tabaksgebruik en problematisch alcoholgebruik. Volgens de inleiding van het akkoord zou het in 2040 zover moeten zijn: we hebben dan met z'n allen veel minder overgewicht, het is geaccepteerd om geen alcohol te drinken en we hebben een volledig rookvrije generatie. Preventie staat in 2040 op het netvlies van elke zorgprofessional. Mensen worden niet meer ziek door stress van opeengestapelde problemen en de negatieve trends waarbij gezondheidsverschillen steeds groter worden, zullen worden omgebogen. Tot zover de inleiding van het akkoord.

Na zo'n inleiding verwacht je natuurlijk stevige maatregelen in het akkoord waarvan we uit onderzoek weten dat het werkt. Ook verwacht je vooral maatregelen die werken bij mensen met een lagere sociaaleconomische positie, omdat zij degenen zijn die het meeste moeite hebben om gezond te leven. Helaas valt dat erg tegen. Met de maatregelen die genoemd staan in het akkoord zullen de ambities voor 2040 niet gehaald worden en zullen mensen met een lagere sociaaleconomische positie nauwelijks geholpen zijn. 
Blog 'Gaat het Preventieakkoord gezondheidsverschillen verkleinen?' door Gera Nagelhout

Hoe kan dat? We weten dat we met stevige overheidsmaatregelen de meeste impact kunnen maken, en dat bijvoorbeeld prijsmaatregelen erg goed werken en vooral goed werken bij mensen met een lagere sociaaleconomische positie. De experts met verstand van zaken zaten aan tafel bij de onderhandelingen over het akkoord en tóch zijn de meest effectieve maatregelen niet in het akkoord opgenomen. Om te weten wat er bij de onderhandelingen over de deelakkoorden voor overgewicht en alcohol is gebeurd, hoef je niet gestudeerd te hebben. Tenminste, als je weet wie er naast de experts nog meer aan tafel zaten: Centraal Bureau Levensmiddelenhandel, de Federatie Nederlandse Levensmiddelen Industrie, Koninklijke Horeca Nederland, VNO-NCW, de Nederlandse Brouwers, de Slijtersunie en Stichting Verantwoorde Alcoholconsumptie. In de deelakkoorden overgewicht en alcohol wordt vooral ingezet op zelfregulering door de industrie en het doen van meer onderzoek voordat er actie wordt ondernomen.

Maar wat is er gebeurd bij het deelakkoord voor tabak? Vanwege een internationaal verdrag dat Nederland ondertekend heeft, is het niet toegestaan dat de tabaksindustrie meepraat over tabaksbeleid. lets wat idealiter natuurlijk ook voor voeding en alcohol zou moeten gelden. In het promotieonderzoek van Nikita Poole zochten we samen met onderzoeksjournalisten van The Investigative Desk uit wat er gebeurd is aan de tabakstafel van het Preventieakkoord. De tabaksindustrie mocht officieel niet meepraten over het tabaksakkoord, maar wist toch via de Tweede Kamer en de coalitie directe invloed uit te oefenen. Zo raakten accijnsverhogingen, neutrale verpakkingen en het uitstalverbod voor tabak verzwakt of vertraagd. 
Blog 'Lees tussen de regels van de tabaksindustrie' door Nikita Poole

In deze podcast vertelt Ties Keyzer over het onderzoek van The Investigative Desk naar de tabaksindustrie en het Preventieakkoord

In dit radioprogramma reageren Gera Nagelhout en Wanda de Kanter op de invloed van de tabaksindustrie op het Preventieakkoord

De impact van tabaksbeleid dat wel wordt ingevoerd, onderzoeken we in het promotieonderzoek van Cloé Geboers en Pragati Hebbar en eerder al in de promotieonderzoeken van Dirk Jan van Mourik, Karin Hummel en mijzelf. Een terugkerende aanbeveling in de drie al gepubliceerde proefschriften over dit thema is dat tabaksbeleidsmaatregelen aangevuld moeten worden met mediacampagnes waarin de gezondheidsschade van roken en meeroken goed wordt uitgelegd. En dat deze campagnes zich vooral moeten richten op mensen met een lager opleidingsniveau, omdat kennis over de gezondheidsrisico's van roken en meeroken onder deze groep achterblijft. Deze aanbeveling is tot op heden nog niet opgevolgd. De Nederlandse overheid financiert liever campagnes die positief en blij zijn en ze heeft de afgelopen jaren ook de focus op mensen met een lagere sociaaleconomische positie losgelaten in mediacampagnes.

\section{Laaghangend fruit}

Hoewel de inleiding van het Preventieakkoord spreekt over het belang van het terugdringen van sociaaleconomische gezondheidsverschillen, lijkt de focus van gezondheidsbevordering door de overheid steeds meer te liggen op de algemene bevolking. In een recent overleg met onder andere het ministerie van VWS waar ik bij was, sprak een ambtenaar over de aantrekkelijkheid van een focus op het laaghangende fruit. Laaghangend fruit is een term uit het bedrijfsleven en de marketing, die tegenwoordig helaas ook regelmatig valt als we het hebben over gezondheidsbeleid. Er wordt mee bedoeld dat we ons het beste kunnen richten op dingen waarmee we met relatief weinig geld en inspanning 
veel resultaat kunnen behalen. De term laaghangend fruit impliceert dat we ons beter kunnen richten op doelgroepen die met een kleiner zetje, of met een generieke maatregel of campagne, al gezonder gaan leven. Dit zijn groepen die minder intensieve en minder langdurige ondersteuning nodig hebben dan mensen met een lagere sociaaleconomische positie. Natuurlijk is het terecht om de vraag te stellen waar hele intensieve en langdurige ondersteuning van betaald moet worden. Maar we moeten ons beseffen dat we nu ook betalen voor de minder goede gezondheid van mensen met een lager inkomen of lager opleidingsniveau.

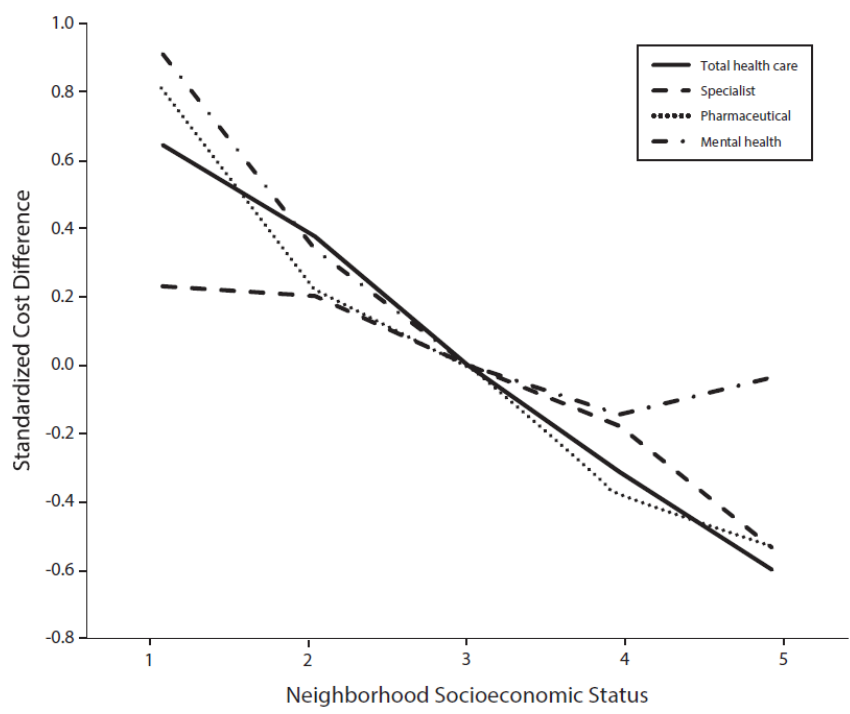

Gezondheidszorgkosten naar sociaaleconomische status op buurtniveau (De Boer et al., 2019)

Zoals je in deze grafiek kunt zien, zijn in Nederland de zorgkosten flink hoger in wijken met een lagere sociaaleconomische positie. Het ligt dus zowel vanuit een gezondheidsperspectief als een economisch perspectief voor de hand om te investeren in de wijken en groepen met de laagste sociaaleconomische positie. De Wetenschappelijke Raad voor het 
Regeringsbeleid (WRR) riep enkele jaren geleden dan ook op om ons te richten op de groepen met het meeste gezondheidspotentieel. Ze constateerde dat de meeste winst qua ziektelast te bereiken was door ons te richten op roken, overgewicht en op problematisch alcoholgebruik. En de WRR vroeg ook om meer aandacht voor de aanpak van psychische problemen.

Hoewel het op basis van deze grafiek heel logisch lijkt om ons te richten op mensen met een lagere sociaaleconomische positie, zitten er prikkels in ons systeem die het juist logischer maken om ons te richten op de mensen voor wie gedragsverandering veel makkelijker is. Ons systeem is namelijk erg gericht op effectiviteitscijfers en kosteneffectiviteit op het niveau van individuele interventies in plaats van op macroniveau. Hoe minder moeite je als interventie-eigenaar doet om mensen te bereiken voor wie leefstijlverandering moeilijker is, hoe beter de effectiviteitscijfers van je interventie zijn en hoe kosteneffectiever je interventie dus lijkt. De prikkel zou juist moeten zijn om zoveel mogelijk mensen te bereiken die de ondersteuning het meeste nodig hebben, zodat we daadwerkelijk de grootste gezondheidswinst behalen.

\section{Naar inclusiever onderzoek}

Graag wil ik nog iets vertellen over mijn plannen voor onderzoek in de komende jaren. Inhoudelijk zal mijn onderzoek natuurlijk blijven gaan over de thema's die ik tijdens deze oratie behandelde. Ik wil graag onderzoek blijven doen naar maatschappelijk relevante thema's, en me hierbij richten op de mensen voor wie gezond leven het lastigste is, zoals Frank en Irene. Ik wil daarin niet alleen focussen op het effect van interventies, maar ook op bereik, proces, mechanismen en implementatie. Stap voor stap zou ik mijn onderzoek graag steeds participatiever en inclusiever willen uitvoeren. Zoals we het Back2Balance-programma hebben ontwikkeld met Frank, Irene en anderen, zou ik in de toekomst graag willen blijven samenwerken met de mensen om wie het gaat. 
Als eerste stap ben ik samen met Latifa Abidi een onderzoek gestart naar inclusief onderzoek. We onderzoeken wat je kunt doen om je onderzoek inclusiever te maken en hoe we medewerkers en studenten van de Universiteit Maastricht kunnen inspireren om inclusiever te werken. Hiermee bedoelen we dat je als onderzoeker geen mensen uitsluit die wel tot de doelgroep van je onderzoek behoren én dat je mensen uit je doelgroep actief betrekt bij je onderzoek.

Blog 'Inclusief onderzoek is juist nu belangrijk' door Gera Nagelhout

Blog 'Inclusief onderzoek vraagt niet om een checklist' door Gera Nagelhout en Julia van Koeveringe

Blog 'Onderzoek doen samen met sociaal kwetsbare doelgroepen: waarom en hoe doe je dat?' door Barbara van Straaten

Als tweede stap ben ik een crowdfundingsactie gestart. Met dat geld wil ik het makkelijker maken om in de toekomst mijn onderzoek en dat van de vakgroep Gezondheidsbevordering vanaf de start participatief en inclusief vorm te kunnen geven. Ik wil een adviesgroep samenstellen met daarin mensen die van weinig geld moeten rondkomen die ons kunnen helpen om interventies en onderzoek over gezond leven te verbeteren.

In deze video vertellen Gera Nagelhout en Latifa Abidi over hun crowdfunding voor een adviesgroep met mensen die van weinig geld moeten rondkomen

Het allerlaatste punt dat ik tijdens deze oratie wil maken is dat we - ook bij de universiteit - méér moeite moeten doen om ons onderzoek breed te communiceren. Mijn promovendi krijgen na het publiceren van hun eerste wetenschappelijke artikel een document van mij met de titel 'Je wetenschappelijke publicatie staat online: wat moet je doen?'. Op dit lijstje staan acties zoals het e-mailen van je publicatie aan anderen, het delen op social media en een blog of opiniestuk schrijven over de resultaten. En ik ben dan ook heel trots als ik blogs, tweets, webinars 
en podcasts van mijn promovendi voorbij zie komen. Ik en mijn promovendi doen dit niet omdat we zo graag aandacht willen, maar omdat we onderzoek doen dat relevant is voor de maatschappij. Door het te delen, zorgen we dat het gelezen wordt. En doordat het gelezen wordt, kan het gebruikt worden in praktijk en beleid.

Blog 'Waarom je als onderzoeker meer moet doen dan een rapport schrijven' door Barbara van Straaten

Blog '3 tips (en 2 slappe excuusjes) voor onderzoekers: zo verspreid je opgedane kennis' door Gera Nagelhout 


\section{Dankwoord}

Deze oratie is bijna ten einde. Maar voordat ik afsluit wil ik nog graag een aantal mensen bedanken. Ik wil niet alleen de mensen bedanken die mij geholpen hebben bij het beklimmen van de academische trap, maar ook degenen die mij onderweg naar de trap hebben vergezeld. Chronologisch gezien begint dat bij mijn familie: mama, papa, Rianne, Maaike en Peter. Dank jullie wel voor jullie steun en liefde! Jaap: dankjewel dat je er altijd voor me bent. Dat je mijn verhalen aanhoort over wetenschap, collega's en deadlines tijdens de vele uren die we tegenwoordig wandelend doorbrengen. Hopelijk kunnen we heel snel weer samen canyoningen, klettersteigen en skiën!

Wim, Matthijs, Marco, Emma, Lieke, Chloe, Tygo, Yara, René, Marja, Eline en oma: jullie natuurlijk ook heel erg bedankt voor jullie gezelschap! De weg naar de academische trap werd ook een stuk aangenamer door de kopjes thee en etentjes met Dagmar, Eveline, Mariska, Sanne, Hilleke en Sanne en de canyontochten met Han, Roos, Maarten, Pieter, Marco, Agatha, Marije, Bas, Jan, Lidewij, Roos en vele anderen.

Mijn eerste treden op de academische trap zette ik samen met Marc, Hein, Bas, Matty, Geoff, Ute en Sara. In het bijzonder Marc en Hein: bedankt voor jullie begeleiding en de mooie samenwerking die gelukkig niet stopte na het behalen van mijn doctorstitel. De volgende treden op de academische trap zette ik samen met mijn promovendi. Zonder promovendi word je geen hoogleraar, maar zonder promovendi wil ik ook helemaal geen hoogleraar worden. Jullie begeleiden vind ik het mooiste deel van dit werk. Bedankt Karin, Dirk Jan, Floor, Margriet, Thomas, Pragati, Nikita, Cloé en Dorine.

Ook wil ik de mannen bedanken die mij aan het denken hebben gezet om hoogleraar te worden en die dit ook daadwerkelijk voor mij wisten te regelen. Bedankt Hein, Onno, Stef, Nanne, Albert, Maurice en Hamit. En om nu niet het beeld neer te zetten dat alleen mannen op hoge plekken 
in universiteiten terecht kunnen komen, bedank ik dan nu ook Rianne (onze rector magnificus) en Annemie (de decaan van onze faculteit).

Natuurlijk wil ik ook al mijn andere collega's bedanken. Maar dan heb ik het over collega's van de vakgroep gezondheidsbevordering en vakgroep huisartsgeneeskunde van de Universiteit Maastricht, collega's van Onderzoeksinstituut IVO en van Platform31. Dat wordt een te lange opsomming, dus in het bijzonder wil ik Barbara, Elske, Latifa en Francine nog bedanken naast de collega's die ik al eerder noemde. En nu kan ik nog wel even doorgaan met allerlei samenwerkingspartners benoemen, bijvoorbeeld van de universiteiten in Amsterdam, Rotterdam, Leiden en Tilburg, hogeschool Rotterdam en Utrecht, mensen van Pharos, FNO, Trimbos, SEO, SineFuma, Indigo, Jellinek, Samen Sterk Zonder Stigma, The Investigative Desk, stichting het Zwarte Gat en ga zo maar door. Maar aangezien dit een online oratie is en het risico heel groot wordt dat jullie dan allemaal wegklikken, moet ik misschien maar eens gaan afronden.

Bedankt dat jullie er allemaal online bij zijn geweest! Ik ben overweldigd door de enorme belangstelling voor mijn oratie. Ik heb het al eerder gezegd: de hoeveelheid mensen die er nu online bij zijn, hadden hier niet in de zaal gepast. Ik hoop dat ik met mijn verhaal aan jullie verwachtingen heb voldaan.

Ik heb gezegd. 


\section{Literatuurlijst}

Abidi, L., Nagelhout, G. E., Spruijt, R., Schutte, H., \& De Vries, H. (2018). Quasi-experimental study evaluating a health promotion program targeting health nutrition, physical activity and social network enhancement for low-income multi-problem households: Study protocol. International Journal of Clinical Trials, 5, 132-141.

Andreyeva, T., Long, M. W., \& Brownell, K. D. (2010). The impact of food prices on consumption: A systematic review of research on the price elasticity of demand for food. American Journal of Public Health, 100, 216-222.

Backholer, K., Sarink, D., Beauchamp, A., Keating, C., Loh, V., Ball, K., Martin, J. \& Peeters, A. (2016). The impact of a tax on sugar-sweetened beverages according to socio-economic position: A systematic review of the evidence. Public Health Nutrition, 19, 3070-3084.

Baum, A., Garofalo, J. P., \& Yali, A. M. (1999). Socioeconomic status and chronic stress: Does stress account for SES effects on health? Annals of the New York Academy of Sciences, $896,131-144$.

Bouma, J. (2019). De sjoemelsigaret: Hoe artsen en overheid de tabaksindustrie vrij spel gaven. Amsterdam/Antwerpen: Uitgeverij Atlas Contact.

Best, D., Vanderplasschen, W., Van de Mheen, D., De Maeyer, J., Colman, C., Vander Laenen, F., Irving, J., Andersson, C., Bellaert, L., Martinelli, T., Graham, S., Hamer, R., \& Nagelhout, G. E. (2018). REC-PATH (Recovery Pathways): Overview of a four-country study of pathways to recovery from problematic drug use. Alcoholism Treatment Quarterly, $36,517-529$.

Bosma, H. (2018). Sociaaleconomische gezondheidsverschillen: Niet wegkijken, maar aanpakken! Tijdschrift voor Gezondheidswetenschappen, 96, 255-256.

Broeders, D., Das, D., Jennissen, R., Tiemeijer, W., \& De Visser, M. (2018). Van verschil naar potentieel: Een realistisch perspectief op de sociaaleconomische gezondheidsverschillen. WRR-Policy Brief 7. Den Haag: Wetenschappelijke Raad voor het Regeringsbeleid.

Burton, R., Henn, C., Lavoie, D., O’Connor, R., Perkins, C., Sweeney, K. et al. (2017). A rapid evidence review of the effectiveness and cost-effectiveness of alcohol control policies: An English perspective. The Lancet, 389(10078), 1558-1580.

Dahlgren, G. \& Whitehead, M. (1991). Policies and strategies to promote social equity in health. Stockholm: Institute for Futures Studies.

Davidson, L., \& White, W. (2007). The concept of recovery as an organizing principle for integrating mental health and addiction services. The Journal of Behavioral Health Services \& Research, 34, 109-120. 
De Been, M., Van den Muijsenbergh, M., \& Duijnhoven, T. (2018). Gezondheid en kwaliteit van zorg voor iedereen. Wat maakt het verschil? Utrecht: Pharos.

De Boer, W. I., Buskens, E., Koning, R. H., \& Mierau, J. O. (2019). Neighborhood socioeconomic status and health care costs: a population-wide study in the Netherlands. American Journal of Public Health, 109, 927-933.

Freudenberg, N. (2014). Lethal but legal: Corporations, consumption, and protecting public health. New York: Oxford University Press.

Haker, F., Hosper, K., \& Van Loenen, T. (2019). Gezondheidsverschillen duurzaam aanpakken: De negen principes voor een succesvolle strategie. Utrecht: Pharos.

Hill, S., Amos, A., Clifford, D., \& Platt, S. (2014). Impact of tobacco control interventions on socioeconomic inequalities in smoking: Review of the evidence. Tobacco Control, 23(e2), 89-97.

Huber, M. A. S. (2014). Towards a new, dynamic concept of health: Its operationalization and use in public health and healthcare, and in evaluating health effects of food. Enschede: Ipskamp Drukkers.

Hummel, K. (2017). It comes and goes in waves: Evaluation of inconsistently implemented tobacco control policies in the Netherlands. Maastricht: Datawyse, Universitaire Pers Maastricht.

Kelly, S. J., \& Ismail, M. (2015). Stress and type 2 diabetes: A review of how stress contributes to the development of type 2 diabetes. Annual Review of Public Health, 36, 441462.

Kok, L., Kroon, L., Meerkerk, G.-J., Nagelhout, G. E., Smits, T., \& Willemsen, M. C. (2020). Beperken van het aantal verkooppunten tabak: Verkenning beleidsopties. Amsterdam: SEO.

Lenkens, M., Nagelhout, G. E., Schenk, L., Sentse, M., Severiens, S., Engbersen, G., Dijkhoff, L., \& Van Lenthe, F. J. "I (really) know what you mean". Mechanisms of experiential peer support for young people with criminal behaviour: A qualitative study. Journal of Crime and Justice. Published Online First: 31 December 2020.

Lenkens, M., Rodenburg, G., Schenk, L., Nagelhout, G. E., Van Lenthe, F. J., Engbersen, G., Sentse, M., Severiens, S., \& Van de Mheen, D. (2020). "I need to do this on my own" Resilience and self-reliance in urban at-risk youths. Deviant Behavior, 41, 1330-1345.

Lenkens, M., Van Lenthe, F. J., Schenk, L., Magnée, T., Sentse, M., Severiens, S., Engbersen, G., \& Nagelhout, G. E. (2019). Experiental peer support and its effects on desistance from delinquent behavior: Protocol paper for a systematic realist literature review. Systematic Reviews, 8, 119 . 
Levy, D. T., Lindblom, E. N., Fleischer, N. L., Thrasher, J., Mohlman, M. K., Zhang, Y., Monshouwer, K., \& Nagelhout, G. E. (2015). Public health effects of restricting retail tobacco product displays and ads. Tobacco Regulatory Science, 1, 61-75.

Magnée, T., Van Straaten, B., 't Hooft, S., \& Nagelhout, G. E. (2020). Zicht op preventieve maatregelen om dakloosheid te voorkomen in Tilburg: Een kwalitatief onderzoek naar routes naar dakloosheid. Den Haag: IVO.

Martinelli, T. F., Nagelhout, G. E., Bellaert, L., Best, D., Vanderplasschen, W., \& Van de Mheen, D. (2020). Comparing three stages of addiction recovery: Long-term recovery and its relation to housing problems, crime, occupation situation, and substance use. Drugs: Education, Prevention \& Policy, 27, 387-396.

Martinelli, T., Van de Mheen, D., Best, D., Vanderplasschen, W., \& Nagelhout, G. E. Are members of mutual aid groups better equipped for addiction recovery? European cross-sectional study into recovery capital, social networks and commitment to sobriety. Drugs: Education, Prevention \& Policy. Published Online First: 9 November 2020.

Meerkerk, G. J., Dewkalie, U., Looyé, M., Sarikaya, Z., Van Straaten, B., \& Nagelhout, G. E. (2019). Handleiding: het organiseren van een stoppen-met-roken-training voor rokers uit kwetsbare groepen. Den Haag: IVO.

Ministerie van VWS (2018). Nationaal Preventieakkoord: Naar een gezonder Nederland. Den Haag: Ministerie van Volksgezondheid, Welzijn en Sport.

Mullainathan, S., Shafir, E. (2013). Scarcity: Why having too little means so much. London: Penguin Books Ltd.

Nagelhout, G. E. (2012). It has been done elsewhere, it can be done everywhere. Impact of smoke-free legislation on smoking. Maastricht: Datawyse, Universitaire Pers Maastricht.

Nagelhout, G. E., Abidi, L., \& De Vries, H. (2021). Reasons for (not) participating in a community-based health promotion program for low-income multi-problem households in the Netherlands: A qualitative study. Health \& Social Care in the Community, 29, 241-249.

Nagelhout, G. E., Abidi, L., Lodder, C., Schutte, H., \& De Vries, H. (2020). Bespreekbaar maken van gezonde leefstijl en het sociale netwerk bij multiprobleemgezinnen door sociaal werkers. Tijdschrift voor Gezondheidswetenschappen, 98, 107-113.

Nagelhout, G. E., Hogeling, L., Spruijt, R., Postma, N., \& De Vries, H. (2017). Barriers and facilitators for health behavior change among adults from multi-problem households: A qualitative study. International Journal of Environmental Research and Public Health, 14, 1229. 
Nagelhout, G. E., Verhagen, D., Loos, V., \& De Vries, H. (2018). Belangrijke randvoorwaarden bij de ontwikkeling van leefstijlinterventies voor mensen met een lage sociaaleconomische status: Een Delphi-onderzoek. Tijdschrift voor Gezondheidswetenschappen, 96, 37-45.

Neter, J. E., Dijkstra, S. C., Visser, M., \& Brouwer, I. A. (2016). Dutch food bank parcels do not meet nutritional guidelines for a healthy diet. British Journal of Nutrition, 116, 526533.

Orford, J., Velleman, R., Natera, G., Templeton, L., \& Copello, A. (2013). Addiction in the family is a major but neglected contributor to the global burden of adult ill-health. Social Science \& Medicine, $78,70-77$.

Poole, N., Solis, S. N., Van Straaten, B., Keyzer, T., Metze, M., \& Nagelhout, G. E. (2020). Factsheet - Argumenten van de tabaksindustrie en door hen voorgestelde overheidsacties: Correspondentie tussen tabaksindustrie en Nederlandse overheid. Den Haag: IVO.

Ronel, N., \& Elisha, E. (2011). A different perspective: Introducing positive criminology. International Journal of Offender Therapy and Comparative Criminology, 55, 305-325.

Sørensen, K., Pelikan, J. M., Röthlin, F., Ganahl, K., Slonska, Z., Doyle, G. et al. (2015). Health literacy in Europe: comparative results of the European health literacy survey (HLS-EU). European Journal of Public Health, 25, 1053-1058.

The Investigative Desk (2020). VVD en tabakssector remmen rookakkoord. Amsterdam: Follow the Money.

Troelstra, S., Magnée, T., Koopman, E., Harting, J., Nagelhout, G. E. (2020). Stoppen-met-rokeninterventies voor mensen met een lagere sociaaleconomische positie: Overzicht van goede voorbeelden en werkzame elementen. Utrecht, Den Haag, Amsterdam: Trimbos-instituut, IVO, Amsterdam UMC.

Twohig-Bennett, C., \& Jones, A. (2018). The health benefits of the great outdoors: A systematic review and meta-analysis of greenspace exposure and health outcomes. Environmental Research, 166, 628-637.

Vaandrager, L., Hogeling, L., Crijns, C., Van Lonkhuijzen, R., De Meere, F., Hermens, N., Snoek, H., Raaijmakers, I., Oosterkamp, E., \& Koelen, M. (2020). Overkoepelend evaluatieonderzoek Gezonde Toekomst Dichterbij. Wageningen, Utrecht: Wageningen University \& Research, Wageningen Economic Research, Verwey-Jonker Instituut.

Van den Brand, F. A., Dohmen, L. M. E., Van Schayck, O. C. P, \& Nagelhout, G. E. (2018). 'Secretly, it's a competition': A qualitative study investigating what helped employees quit smoking during a workplace smoking cessation group training programme with incentives. BMJ Open, 8, eo23917. 
Van den Brand, F. A., Magnée, T., De Haan-Bouma, L., Barendregt, C., Chavannes, N. H., Van Schayck, O. C. P., \& Nagelhout, G. E. (2019). Implementation of financial incentives for successful smoking cessation in real-life company settings: A qualitative needs assessment among employers. International Journal of Environmental Research and Public Health, 16, 5135.

Van den Brand, F. A., Nagelhout, G. E., Reda, A. A., Winkens, B., Evers, S. M. A. A., Kotz, D., $\&$ Van Schayck, O. C. P. (2017). Healthcare financing systems for increasing the use of tobacco dependence treatment. Cochrane Database of Systematic Reviews, 9 , CDoo4305.

Van den Brand, F. A., Nagelhout, G. E., Winkens, B., Chavannes, N. H., \& Van Schayck, O. C. P. (2018). Effect of a workplace-based group training programme combined with financial incentives on smoking cessation: A cluster-randomised controlled trial. The Lancet Public Health, 3, e536-e544.

Van Mourik, D. J. A. (2019). Evaluating tobacco control policies: European Union's health warnings and dissuasive cigarettes. Maastricht: ProefschriftMaken.

Van Straaten, B. (2016). On the Way Up? Exploring homelessness and stable housing among homeless people in the Netherlands. Rotterdam: IVO.

Van Straaten, B., Meerkerk, G. J., Van den Brand, F. A., Lucas, P., De Wit, N., \& Nagelhout, G. E. (2020). How can people in a vulnerable position be recruited to participate in a community-based smoking cessation programme and how do they evaluate it? A qualitative study among participants and professionals. Tobacco Prevention \& Cessation, 6, 64 .

Vermeulen, W., Schwartz, T., Van Straaten, B., Kroon, L., Smits, T., Nagelhout, G., Kok, L. (2020). Beschikbaarheid van alcohol: Nulmeting en verkenning van beleidsopties. Amsterdam: SEO. 
